\title{
Biosocial Synchrony on Sumba: Multispecies Relationships and Environmental Variations in Indonesia. By Cynthia T. Fowler. 2016. Lexington Books, Lanham. 137 pp.
}

\author{
F. Merlin Franco ${ }^{1 *}$ \\ ${ }^{1}$ Institute of Asian Studies, Universiti Brunei Darussalam, Brunei Darussalam. \\ *merlin.francis@ubd.edu.bn
}

Received August 9, 2018

OPEN ठ ACCESS

Accepted September 5, 2018

DOI 10.14237/ebl.9.2.2018.1374

Copyright (c) 2018 by the author(s) licensee Society of Ethnobiology. This is an open-access article distributed under the terms of the Creative Commons Attribution-NonCommercial 4.0 International Public License (https://creativecommons.org/licenses/by-nc/4.0), which permits non-commercial use, distribution, and reproduction in any medium, provided the original author and source are credited.

We call them dumb animals, and so they are, for they cannot tell us how they feel, but they do not suffer less because they have no words.

$$
\text { - Anna Sewell, Black Beauty }
$$

Almost one hundred and forty years after Black Beauty was published, we have evidence to show that nonhuman animals such as horses can read our facial expressions and also remember our respective emotional state (Proops et al. 2018). We are just beginning to understand the role of mycorrhizal networks in sustaining forests (Gorzelak et al. 2015), the relevance of folk taxonomy in discovering new species (Geissmann et al. 2010), the importance of considering polyherbal formulations instead of principal ingredients (Sar et al. 2018), and the influence of lunar cycles on pollination of certain plants (Rydin and Bolinder 2015), while we are still undecided if lunar cycles have an influence on human psyche and wellbeing (Chakraborty 2013; Owens and McGowen 2006). Although perhaps none of the above would surprise a member of an indigenous community, any claims related to the above would have been laughed off by most in the scientific fraternity a few decades ago. Except, perhaps, for that unique breed of researchers called ethnobiologists who spend their life working with indigenous peoples, understanding their knowledge and way of life. Yet, we should remember that a good number of us have been caught in an eternal quest for scientific validation of traditional/indigenous/local knowledge systems - the numerous research articles comparing folk and scientific classification systems are just an example.

Fowler's Biosocial Synchrony on Sumba is a subtle reminder for ethnobiologists/anthropologists to view indigenous beliefs and knowledge systems from the perspective of the respective communities. Are anthropologists also capable of adopting the perspectives of the non-living? Fowler answers her own question by employing what she calls a "manipulation of perspectives" to promote an understanding of biosocial beings from the perspectives of seaworms, their worshippers, the celestial bodies, and human bodies. Fowler's arguments draw strength from the huge volume of data collected since 1997 in collaboration with the Kodi people of tana nale or the land of seaworms, effectively interweaving ethnography, astronomy, marine biology, and ecology. The crux of the book is based on Ingold's theory of biosocial becomings, and the author has successfully portrayed how indigenous understandings see no boundaries between the living and the non-living, the close and the distant, or nature and culture.

The alignments of the sun, moon, and the earth influence the mating behavior of the seaworms which in turn influence the ritualistic, dietary and agricultural calendar of the Kodi people. Kodi identity rests on their relationship with the seaworms, who are recognized as "fully realized selves" (p. 21) in contrast to the formal western notion of seeing non-human animals as lower beings. In fact, many Kodi believe that they are descendants of entities who were partly 
non-human and continue to affirm their connection through kinships. Fowler argues that the swarming of Kodi at the Sumba reefs during seaworm spawning season is a manifestation of their desire to socialize with the polychaetes. The human rhythms run parallel to that of the moon with whom the humans engage in a reciprocal relationship. Thus, the various lunar phases are associated with the good and bad of Kodi life. The position of the moon signals to the Kodi priests the commencement of the spawning season, while the spawning of seaworms indicate that it is time for the young men to woo their lovers on the beaches close to seaworms. The Kodi calendar that is based on the moon and the seaworm rhythms determines landscape and seascape modification activities that include agriculture, harvesting of worms, horticulture, arboriculture, animal husbandry, forestry, hunting, gathering, and fishing. Thus, Kodi and the polychaetes, together with the moon, 384,400 $\mathrm{km}$ away, are all ecosystem engineers.

The book makes many crucial contributions to ethnobiology beyond biosocial theory. Like Hoskins (1993), Fowler's work also recognizes the importance of seaworms in the Kodi lunar calendar and the institution of calendar keepers (seaworm priests). Yet, she does not delve explicitly into the importance of calendars, as Hoskins (1993) did, and leaves it to the reader to tease out the significance of calendars from the voluminous data presented. Thus, it could be said that the book also adds to the growing volume of literature on indigenous calendars. For ethnobiologists interested in folk taxonomy, transtaxa such as Biri Koni and Mother Seaworm will be of immense interest. Mother Seaworm is a seaworm; she is also a spirit and ancestor with various niches such as near shore, deep water, ocean, atmosphere, or land. Biri Koni was once a human who was elevated to the rank of spirit through sacrifice. She is also the sum total of all domesticated crops including job's-tears, maize, leafy greens, sorghum, rice, and cassava. The occurrence of transtaxa that exist fluidly across various categories otherwise considered separate has rarely been studied. The same applies to doublegendered taxa such as Great Mother Great Father that are commonly encountered in Southeast Asia but often overlooked.

The positioning of the sun, the moon, and the seaworms along with the Kodi as ecosystem engineers will be of interest to ethnobiologists studying human niche construction. Fowler's book is a comprehensive treatise on Kodi cosmology, traditional ecological knowledge, folklore, beliefs, and language, which also makes it important for the study of biocultural diversity - a key term that is, however, not used in this book.

\section{References Cited}

Chakraborty, U. 2014. Effects of Different Phases of the Lunar Month on Humans. Biological Rhythm

Research 45:383-396. DOI:10.1080/09291016.2013.830508.

Geissmann, T., N. Lwin, S. S. Aung, T. N. Aung, Z. M. Aung, T. H. Hla, M. Grindley, and F. Momberg. 2011. A New Species of Snub-Nosed Monkey, Genus Rbinopithecus Milne-Edwards, 1872 (Primates, Colobinae), from Northern Kachin State, Northeastern Myanmar. American Journal of Primatology 73:96-107. DOI:10.1002/ajp.20894.

Gorzelak, M. A., A. K. Asay, B. J. Pickles, and S. W. Simard. 2015. Inter-plant Communication through Mycorrhizal Networks Mediates Complex Adaptive Behaviour in Plant Communities. AoB Plants 7:plv050. DOI:10.1093/aobpla/plv050.

Hoskins, J. 1993. The Play of Time: Kodi Perspectives on Calendars, History, and Exchange. University of California Press, Berkeley, CA.

Owens, M., and I. W. McGowan. 2006. Madness and the Moon: The Lunar Cycle and Psychopathology. German Journal of Psychiatry 9:123-127.

Proops, L., K. Grounds, A. V. Smith, and K. McComb. 2018. Animals Remember Previous Facial Expressions that Specific Humans Have Exhibited. Current Biology 28:1428-1432. DOI:10.1016/ j.cub.2018.03.035.

Rydin, C., and K. Bolinder. 2015. Moonlight Pollination in the Gymnosperm Ephedra (Gnetales). Biology Letters 11:20140993. DOI:10.1098/ rsbl.2014.0993.

Sar, T. K. S., I. Samanta, A. Mahanti, S. Akhtar, and J. R. Dash. 2018. Potential of a Polyherbal Drug to Prevent Antimicrobial Resistance in Bacteria to Antibiotics. Scientific Reports 8:10899. DOI:10.1038/ s41598-018-28966-x. 